scientific infrastructure to serve the whole continent, such as a biobank of gene or tissue samples, are often dismayed to find that there is no appropriate source of funding - no matter how useful the project. Scientists in Europe also find that the management of intellectual-property rights varies between the member states. Scores of issues such as these make it hard for researchers to properly exploit the scale of the European Research Area.

Overcoming such obstacles is rightly seen as important in the European Union's push to become more scientifically competitive with the United States, where scientists already enjoy the advantages of ready interaction with a vast array of colleagues in a nation of 300 million people.

The green paper released by the European Commission on 4 April outlines the existing problems and asks for ideas from interested parties, including scientists, on what should be done to fix them. The consultation process will include a questionnaire that will appear on the commission's website (htp://ec.europa.eu/research/era) from 1 May until August, and a conference in Portugal this autumn. Early next year, the commission will use this feedback to help it draw up decrees or legislation that it thinks will help strengthen the European Research Area.

But the commission does not have the clout to implement such reforms on its own. Its main political master, the Council of Ministers, committed itself in 2000 to improving competitivity in research and innovation by 2010 - by facilitating the mobility of researchers, for example. But the member states whose leaders make up the council have not yet implemented the changes in their home countries that are needed for the European Research Area to function effectively.

The European Commission, whose Framework research programmes still account for only about one-twentieth of the member states' total spending on research, can do little more than encourage national governments to realize that far more cooperation at the European level will benefit them all. Perhaps the most sensitive issue in this regard is to get more national tax revenue to be pooled for genuinely European projects.

None of these problems will be solved overnight. But it is important that the commission gains the explicit support of both industrial and academic scientists in its long march towards European research unity. The consultation will allow individual researchers to put on the record the cross-border issues that confront them in their working lives. As many as possible should fill in the questionnaire and make their voices heard.

\section{When employees attack}

\section{Government scientists should be able to comment publicly - within reason.}

B admouthing one's government is a fashionable pastime in some parts of the world. Many US climatologists, even those who receive federal funding, have grave reservations about the White House's continued neglect of international climate agreements, and they aren't shy about saying so. In Britain, meanwhile, scientists as well as political analysts have been quick to criticize the government's plan to spend billions on renewing the national fleet of nuclear-weapons submarines.

Roll those two examples together, and transplant them into a society where freedom of speech is often seen as being under pressure from several directions, and you get the case of Claudio Mendoza. Until recently the head of a government physics laboratory in Venezuela, Mendoza has been demoted after making sarcastic comments about the government over what he regards as its tendency to ignore scientists and their advice (see page 711).

What infuriated Mendoza's paymasters most was probably his suggestion - made in a newspaper article promoting a play about nuclear weapons - that president Hugo Chávez might want to pursue a nuclear-weapons programme and that, if he did so, he was liable to fail because of this alleged disdain for expert advice.

Mendoza's comments were not made in any official capacity (his article was signed, with no affiliation given), raising the fraught question of whether senior government scientists should be free to make disparaging public comments about the state institutions that they serve, when they are away from work.

On a facile level, this is a disagreement about whether it is acceptable for someone to be fired because their bosses can't take a joke. In many countries, acerbic comments about the machinations of politics are a valid and effective mode of public discourse.

But, of course, a line has to be drawn somewhere. It is hard to escape the feeling that, in this case, it has been drawn in the wrong place. Many civil servants in other countries might expect a dressing-down if they behaved in this way, but might justifiably argue that they have a right to express a grievance. The message coming from Mendoza's bosses within the Venezuelan national research institute is an unsavoury one. His removal from a management position implies that someone who voices contrary opinions is not fit to be a lab head. What's more, Mendoza has been warned that he had better clam up if he doesn't want to lose his job altogether.

The play that Mendoza was writing about was Michael Frayn's Copenhagen, the international hit that deals with a crucial 1941 meeting between Niels Bohr and Werner Heisenberg, and their struggle to comprehend the feasibility and consequences of developing nuclear weapons during the Second World War (see Nature 394, 735; 1998).

One of the reasons for the play's success was general interest in what physicists of Bohr's generation thought about the issues surrounding nuclear weapons. Of course, these thoughts only became public some time after the United States had built and used the bomb. But times have moved on, and people in Caracas, as elsewhere, would benefit if their scientists were be able to participate openly in public debate on nuclear policy. 